\title{
AMSR2 SOIL MOISTURE PRODUCT VALIDATION
}

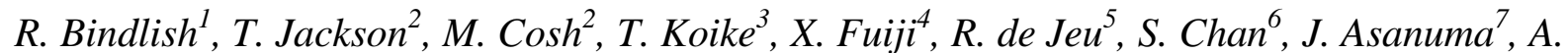 \\ Berg $^{8}$, D. Bosch ${ }^{9}$, T. Caldwell ${ }^{10}$, C. Holyfield Collins ${ }^{11}$, H. McNairn ${ }^{12}$, J. Martínez-Fernández ${ }^{13}$, \\ J. Prueger ${ }^{14}$, M. Seyfried ${ }^{15}$, P. Starks ${ }^{16}$, Z. Su $^{17}$, M. Thibeault $^{18}$, J. Walker $^{19}$ \\ ${ }^{1}$ NASA Goddard Space Flight Center, Greenbelt, MD, USA \\ ${ }^{2}$ USDA ARS Hydrology and Remote Sensing Lab, Beltsville, MD, USA \\ ${ }^{3}$ University of Tokyo, Tokyo, Japan \\ ${ }^{4}$ Remote Sensing Technology Center of Japan, Tokyo, Japan \\ ${ }^{5}$ Vandersat, Amsterdam, The Netherlands \\ ${ }^{6}$ Jet Propulsion Laboratory, California Institute of Technology, Pasadena, CA, USA \\ ${ }^{7}$ University of Tsukuba, Tsukuba, Japan \\ ${ }^{8}$ University of Guelph, Guelph, Canada \\ ${ }^{9}$ USDA ARS Southeast Watershed Research Center, Tifton, GA, USA \\ ${ }^{10}$ University of Texas, Austin, TX, USA \\ ${ }^{11}$ USDA ARS Southwest Watershed Research Center, Tucson, AZ, USA \\ ${ }^{12}$ Agriculture and Agri-Food Canada, Ottawa, Canada \\ ${ }^{13}$ University of Salamanca, Salamanca, Spain \\ ${ }^{14}$ USDA ARS National Laboratory for Agriculture and the Environment, Ames, IA, USA \\ ${ }^{15}$ USDA ARS Northwest Watershed Research Center, Boise, ID, USA \\ ${ }^{16}$ USDA ARS Grazinglands Research Laboratory, El Reno, OK, USA \\ ${ }^{17}$ University of Twente, Enschede, Netherlands \\ ${ }^{18}$ Comisión Nacional de Actividades Espaciales (CONAE), Buenos Aires, Argentina \\ ${ }^{19}$ Monash University, Clayton, Australia
}

\begin{abstract}
The Advanced Microwave Scanning Radiometer 2 (AMSR2) is part of the Global Change Observation Mission-Water (GCOM-W) mission. AMSR2 fills the void left by the loss of the Advanced Microwave Scanning Radiometer-Earth Observing System (AMSR-E) after almost 10 years. Both missions provide brightness temperature observations that are used to retrieve soil moisture. Merging AMSR-E and AMSR2 will help build a consistent long-term dataset. Before tackling the integration of AMSR-E and AMSR2 it is necessary to conduct a thorough validation and assessment of the AMSR2 soil moisture products. This study focuses on validation of the AMSR2 soil moisture products by comparison with in situ reference data from a set of core validation sites. Three products that rely on different algorithms were evaluated; the JAXA Soil Moisture Algorithm (JAXA), the Land Parameter Retrieval Model (LPRM), and the Single Channel Algorithm (SCA). Results indicate that overall the SCA has the best performance based upon the metrics considered.
\end{abstract}

Index Terms - Soil moisture, AMSR2, validation

\section{INTRODUCTION}

The Advanced Microwave Scanning Radiometer-Earth Observing System (AMSR-E) projects of the National Aeronautics and Space Administration (NASA) and the Japan Aerospace Exploration Agency (JAXA) were the first satellite programs to incorporate soil moisture as a standard product [1-2]. AMSR-E based soil moisture products developed using different algorithm concepts have been evaluated and inter-compared in a number of studies, under a range of ground and climate conditions and using a variety of metrics [3-5]. These evaluations have shown differences between the AMSR-E products in terms of biases, sensitivities and temporal responses.

AMSR-E was launched in May 2002 and stopped normal operations in October 2011. As a follow-on to the AMSR-E mission, the Japan Aerospace Exploration Agency (JAXA) developed the Advanced Microwave Scanning Radiometer 2 (AMSR2) as part of the Global Change Observation Mission-Water (GCOM-W) mission. This was launched on May 18, 2012 (and began routine data production in July 2012), leaving a several months gap from the end of AMSR-E (actual products began in June 2012). 
Merging AMSR-E and AMSR2 will help build a consistent long-term dataset for monitoring this component of the Earth's water cycle. However, before tackling the integration of AMSR-E and AMSR2 it is necessary to conduct a thorough validation and assessment of the AMSR2 soil moisture products. Some preliminary studies have been conducted [6-9]. Here we will focus on Stage 1 validation of the AMSR2 soil moisture products as defined by the Committee on Earth Observing Satellites [10]: product accuracy is assessed from a small (typically < 30 ) set of locations and time periods by comparison with in situ or other suitable reference data. The key issue in conducting this stage of soil moisture product validation is accounting for the disparity in spatial scales between satellite and in situ observations. For this investigation we adapted the approaches and resources developed for validation of the Soil Moisture Active Passive (SMAP) mission. SMAP established a set of core validation sites (CVS) that included replicate sampling within the satellite footprint/grid. Utilizing core sites addresses the weakness of trying to up-scale sparse networks.

There are several soil moisture products that are publically available from JAXA and NASA. Here three alternatives are evaluated using in situ data from the core validation sites. A standard set of metrics is used for assessing performance.

\section{SOIL MOISTURE PRODUCTS AND ALGORITHMS}

Retrieval of soil moisture from brightness temperature (TB) observations is based on a well-known approximation to the radiative transfer equation, commonly known in the passive microwave soil moisture community as the tau-omega model [11]. The TB will be dependent on the sensor features (frequency, polarization, viewing angle) and target variables (soil moisture, roughness, vegetation properties, and physical temperature of both the soil and vegetation). In order to attempt the estimation of soil moisture, assumptions and simplifications are made. These simplifications are incorporated into the retrieval algorithm. There is typically more than one path that can be followed and as a result several soil moisture algorithms have been implemented for AMSR2 (and AMSR-E). For this investigation we will use three products that rely on different algorithms; the JAXA Soil Moisture Algorithm (JAXA) [12-13], the Single Channel Algorithm (SCA) [14-15] and Land Parameter Retrieval Model (LPRM) [16-17]. Analysis was limited to those products provided (or will be) by an agency. There are other algorithms but the products are not widely available.

\section{CORE VALIDATION SITES}

In an attempt to ensure the geographic distribution and diversity of conditions of the CVS, SMAP partnered with investigators $(\mathrm{Cal} / \mathrm{Val}$ Partners) around the globe. The CVS candidates were selected based on a minimum requirement of providing continuous soil moisture measurements at $\sim 5 \mathrm{~cm}$ depth with replication within a SMAP grid cell (36-km for the passive-based products). More details on the sites and selection process can be found in [18]. The optimal grid was identified for each CVS and an up-scaling function for the in situ network was established.

The list of CVS utilized in this investigation is the same as that employed by SMAP and is shown in Table 1. The general features, number of sites and up-scaling approach are also listed in the table. Some modifications were made to those selected by SMAP because some SMAP sites were not operational for the available AMSR2 period of record.

Table 1. Core Validation Sites

\begin{tabular}{|c|c|c|c|}
\hline Site Name & Region & $\begin{array}{c}\text { Climate } \\
\text { regime }\end{array}$ & $\begin{array}{c}\text { IGBP Land } \\
\text { Cover }\end{array}$ \\
\hline $\begin{array}{c}\text { Walnut } \\
\text { Gulch }\end{array}$ & $\begin{array}{c}\text { USA } \\
\text { (Arizona) }\end{array}$ & Arid & Shrub open \\
\hline $\begin{array}{c}\text { Reynolds } \\
\text { Creek }\end{array}$ & $\begin{array}{c}\text { USA } \\
\text { (Idaho) }\end{array}$ & Arid & Grasslands \\
\hline TxSON & $\begin{array}{c}\text { USA } \\
\text { (Texas) }\end{array}$ & Temperate & Grasslands \\
\hline Fort Cobb & $\begin{array}{c}\text { USA } \\
\text { (Oklahoma) }\end{array}$ & Temperate & Grasslands \\
\hline $\begin{array}{c}\text { Little } \\
\text { Washita }\end{array}$ & $\begin{array}{c}\text { USA } \\
\text { (Oklahoma) }\end{array}$ & Temperate & Grasslands \\
\hline South Fork & $\begin{array}{c}\text { USA } \\
\text { (Iowa) }\end{array}$ & Cold & Croplands \\
\hline Little River & $\begin{array}{c}\text { USA } \\
\text { Georgia) }\end{array}$ & Temperate & $\begin{array}{c}\text { Cropland/ } \\
\text { natural mosaic }\end{array}$ \\
\hline Kenaston & Canada & Cold & Croplands \\
\hline Carman & Canada & Cold & Croplands \\
\hline Monte Buey & Argentina & Arid & Croplands \\
\hline REMEDHUS & Spain & Temperate & Croplands \\
\hline Twente & $\begin{array}{c}\text { The } \\
\text { Netherlands }\end{array}$ & Temperate & $\begin{array}{c}\text { Cropland/ } \\
\text { natural mosaic }\end{array}$ \\
\hline Mongolian & Mongolia & Cold & Grasslands \\
\hline Kyeamba & Australia & Semi-Arid & $\begin{array}{c}\text { Croplands/ } \\
\text { Grasslands }\end{array}$ \\
\hline
\end{tabular}




\section{METRICS}

Based on precedents established by previous studies such as [3] and [15] and guidance provided by [19] the following metrics are used to assess the performance

- Root Mean Square Error (RMSE)

- Bias

- Unbiased RMSE (ubRMSE)

- Correlation (R)

\section{PRELIMINARY RESULTS}

All satellite soil moisture data utilized in this analysis were footprint retrievals, as opposed to gridded products. For each CVS, the product footprints that fell within the boundaries were averaged to estimate the surface soil moisture of the $36-\mathrm{km}$ validation grid cell. This was performed for each available day from July 2012 to July 2016, to produce a four-year record for the ascending and descending passes (separately). For in situ soil moisture, all dates and times corresponding to a satellite product were extracted.

Tables 2 and 3 summarize the overall results for the descending and ascending passes respectively. The SCA has the lowest ubRMSE and bias. The SCA ubRMSE is slightly better than that of the JAXA product but its bias is smaller than JAXA. For descending the LPRM has the poorest values of the ubRMSE and bias but has the highest correlation, slightly better than the SCA. The bias of the LPRM improves for ascending retrievals.

Table 2. AMSR2 Validation Results (Descending)

\begin{tabular}{|c|c|c|c|c|}
\hline Product & $\begin{array}{c}\text { ubRMSE } \\
\left(\mathrm{m}^{3} / \mathrm{m}^{3}\right)\end{array}$ & $\begin{array}{c}\text { Bias } \\
\left(\mathrm{m}^{3} / \mathrm{m}^{3}\right)\end{array}$ & $\begin{array}{c}\text { RMSE } \\
\left(\mathrm{m}^{3} / \mathrm{m}^{3}\right)\end{array}$ & $\mathrm{R}$ \\
\hline JAXA & 0.059 & -0.089 & 0.111 & 0.502 \\
\hline SCA & 0.055 & -0.047 & 0.080 & 0.569 \\
\hline LPRM & 0.088 & 0.100 & 0.137 & 0.601 \\
\hline
\end{tabular}

Table 3. AMSR2 Validation Results (Ascending)

\begin{tabular}{|c|c|c|c|c|}
\hline Product & $\begin{array}{c}\text { ubRMSE } \\
\left(\mathrm{m}^{3} / \mathrm{m}^{3}\right)\end{array}$ & $\begin{array}{c}\text { Bias } \\
\left(\mathrm{m}^{3} / \mathrm{m}^{3}\right)\end{array}$ & $\begin{array}{c}\text { RMSE } \\
\left(\mathrm{m}^{3} / \mathrm{m}^{3}\right)\end{array}$ & $\mathrm{R}$ \\
\hline JAXA & 0.057 & -0.081 & 0.102 & 0.541 \\
\hline SCA & 0.056 & -0.046 & 0.081 & 0.586 \\
\hline LPRM & 0.090 & 0.045 & 0.104 & 0.540 \\
\hline
\end{tabular}

CVS sites exhibited a range of response that are being analyzed. Additional analyses involving ascending observations, vegetation levels, and AMSR-E comparisons are being conducted.

\section{SUMMARY}

Three soil moisture products derived from AMSR2 brightness temperatures were compared to in situ soil moisture observations from core validation sites. Performance metrics indicated that the Single Channel Algorithm had the best overall performance.

\section{REFERENCES}

[1] Shibata, A., K. Imaoka, K., and T. Koike, "AMSR/AMSR-E level 2 and 3 algorithm developments and data validation plans of NASDA," IEEE Trans. Geosci. Remote Sens., 41: 195-203, 2003.

[2] Njoku, E.G., T.J. Jackson, V. Lakshmi, T.K. Chan, and S.V. Nghiem, "Soil moisture retrieval from AMSR-E," IEEE Trans. Geosci. Remote Sens. 41: 215-229, 2003.

[3] Jackson, T.J., M.H. Cosh, R. Bindlish, P.J. Starks, D.D. Bosch, M.S. Seyfried, D.C. Goodrich, and M.S. Moran, "Validation of Advanced Microwave Scanning Radiometer soil moisture products," IEEE Trans. Geosci. Remote Sens., 48: 4256-4272, 2010.

[4] Mladenova, T. Jackson, E. Njoku, R. Bindlish, S. Chan, M. Cosh, T. Holmes, R. de Jeu, L. Jones, and J. Kimball, J., "Remote monitoring of soil moisture using passive microwave-based techniques - theoretical basis and overview of selected algorithms for AMSR-E," Remote Sens. Environ., 144: 197-213, 2014.

[5] Draper, C.S., J.P. Walker, P.J. Steinle, R.A. de Jeu, and T.A. Holmes, "An evaluation of AMSR-E derived soil moisture over Australia," Remote Sens. Environ., 113: 703$710,2009$.

[6] Wu, Q., H. Liu, L. Wang, Lei, and C. Deng, "Evaluation of AMSR2 soil moisture products over the contiguous United States using in situ data from the International Soil Moisture Network," Int. J. Appl. Earth Obs. Geoinf., 45: 187-199, 2016.

[7] Kim, S., Y.Y. Liu, F.M. Johnson, R.M. Parinussa, and A. Sharma, "A global comparison of alternate AMSR2 soil moisture products: Why do they differ?," Remote Sens. Environ., 161: 43-62, 2015.

[8] Cho, E., H. Moon, and M. Choi, "First assessment of the Advanced Microwave Scanning Radiometer 2 (AMSR2) soil moisture contents in Northeast Asia," J. Meteorol. Soc. Japan, 93: 117-129, 2015.

[9] Parinussa, R.M., T.R. Holmes, N. Wanders, W.A. Dorigo, and R.A. de Jeu, "A preliminary study towards consistent soil moisture from AMSR2," J. Hydrometeorology, 16: 932-947, 2014.

[10] Committee on Earth Observation Satellites (CEOS) Working Group on Calibration and Validation (WGCV): http://calvalportal.ceos.org/CalValPortal/welcome.do and WWW: Land Products Sub-Group of Committee on Earth Observation Satellites (CEOS) Working Group on Calibration and Validation (WGCV): http://lpvs.gsfc.nasa.gov.

[11] Mo, T., B.J. Choudhury, T.J. Schmugge, J.R. Wang, and T.J. Jackson, "A model for microwave emission from 
vegetation-covered fields," Journal of Geophysical Research, 87(C13): 11229-11237, 1982.

[12] Koike, T., Y. Nakamura, I. Kaihotsu, G. Davva, N. Matsuura, K. Tamagawa, and H. Fujii, "Development of an advanced microwave scanning radiometer (AMSR-E) algorithm of soil moisture and vegetation water content," Annual Journal of Hydraulic Engineering, Japanese Society of Civil Engineers, 48: 217-222, 2004.

[13] Fujii, H., T. Koike, and K. Imaoka, "Improvement of the AMSR-E algorithm for soil moisture estimation by introducing a fractional vegetation coverage dataset derived from MODIS data," J. Remote Sens. Soc. Japan, 29: 282-292, 2009.

[14] Jackson, T.J., "Measuring surface soil moisture using passive microwave remote sensing," Hydrological Processes, 7: 139-152, 1993.

[15] Chan, S., R. Bindlish, P. O’Neill, E. Njoku, T. Jackson, A. Colliander, F. Chen, M. Bürgin, S. Dunbar, J. Piepmeier, S. Yueh, D. Entekhabi, M. Cosh, T. Caldwell, J. Walker, X. Wu, A. Berg, T. Rowlandson, A. Pacheco, H. McNairn, M. Thibeault, J. Martínez-Fernández, Á. González-Zamora, M. Seyfried, D. Bosch, P. Starks, D. Goodrich, J. Prueger, M. Palecki, E. Small, J.C. Calvet, W. Crow, and Y. Kerr, "Assessment of the SMAP Level 2 passive soil moisture product," IEEE Trans. Geosci. Remote Sens., 54: 4994-5007, 2016.
[16] Owe, M., R.A. de Jeu, and J. Walker, "A methodology for surface soil moisture and vegetation optical depth retrieval using the microwave polarization difference index," IEEE Trans. Geosci. Remote Sens., 39: 1643-1654, 2011.

[17] Meesters, A. G. C. A., De Jeu, R. A. M., \& Owe, M. (2005). Analytical derivation of the vegetation optical depth from the microwave polarization difference index. IEEE Geoscience and Remote Sensing Letters, 2(2), 121-123.

[18] Colliander, A., T.J. Jackson, R. Bindlish, S. Chan, N. Das, N., S. Kim, M.H. Cosh, R.S. Dunbar, L., Dang, L. Pashaian, J. Asanuma, K. Aida, A. Berg, T. Rowlandson, D. Bosch, T. Caldwell, K. Caylor, D. Goodrich, H. al Jassar, E. Lopez-Baeza, J. Martínez-Fernández, A. González-Zamora, S. Livingston, H. McNairn, A. Pacheco, M. Moghaddam, C. Montzka, C. Notarnicola, G. Niedrist, T. Pellarin, J. Prueger, J. Pulliainen, K. Rautiainen, J. Ramos, M. Seyfried, P. Starks, Z. Su, Y. Zeng, R. van der Velde, M. Thibeault, W. Dorigo, M. Vreugdenhil, J.P. Walker, X. Wu, A. Monerris, P. E. O’Neill, D. Entekhabii, E. G. Njoku and S. Yueh, "Validation of SMAP surface soil moisture products with core validation sites," Remote Sensing of Environment, in review.

[19] Entekhabi, D., R.H. Reichle, R.D. Koster, and W.T. Crow, "Performance metrics for soil moisture retrievals and application requirements," J. Hydrometeorology, 11: 832-840, 2010. 